\title{
AC 2007-1902: STUDENT DELIVERABLES AND INSTRUCTION FOR A SENIOR DESIGN PROGRAM COURSE
}

\section{James Conrad, University of North Carolina-Charlotte}

James M.Conrad received his bachelor's degree in computer science from the University of Illinois, Urbana,and his master's and doctorate degrees in computer engineering from North Carolina State University. He is currently an associate professor at the University of North Carolina at Charlotte. He has served as an assistant professor at the University of Arkansas and as an instructor at North Carolina State University. He has also worked at IBM in Research Triangle Park, North Carolina, and Houston, Texas; at Ericsson/Sony Ericsson in Research Triangle Park, North Carolina; and at BPM Technology in Greenville, South Carolina. Dr. Conrad is a Senior Member of the IEEE and a Certified Project Management Professional (PMP). He is also a member of ASEE, Eta Kappa $\mathrm{Nu}$, the Project Management Institute, and the IEEE Computer Society. He is the author of numerous books, book chapters, journal articles, and conference papers in the areas of robotics, parallel processing, artificial intelligence, and engineering education.

\section{Daniel Hoch, University of North Carolina-Charlotte}

Dan Hoch is a faculty associate in the Engineering Technology Department at the University of North Carolina at Charlotte. He teaches courses in the Mechanical Engineering Technology department such as machining practices, senior design, and thermodynamics. Dan's areas of interest are related to thermal fluid design, internal combustion engines, and energy conversion.

Prior to his current position at UNC-Charlotte, Dan worked for Mercury Marine in Fond du lac, Wisconsin developing 2-stroke and 4-stroke engines and propulsion systems. After completing his graduate studies at the University of Wisconsin, Madison, Dan spent two years working as a research engineer in the Mechanical Engineering Department at the UW-Madison focusing on cryogenic and thermal fluid systems.

\section{Frank Skinner, University of North Carolina-Charlotte}

Frank Skinner is currently the director of Industrial Solutions at the Department of Mechanical Engineering and Engineering Science at University of North Carolina - Charlotte. His industry positions include president of Robo-Tech Systems,Inc., senior market development engineer at GE and manager of engineering at Advanced Products Corp. 


\title{
Student Deliverables and Instruction for a Senior Design Program Course
}

\begin{abstract}
Nearly all of the senior design courses at the University of North Carolina at Charlotte (UNC Charlotte) were project-only courses. The Departments of Electrical and Computer Engineering, Mechanical Engineering, and Engineering Technology all had students work on their projects with minimal instruction during the two semester course. Further, the students were only required to submit documentation at the end of each semester. The first semester's documentation typically looked more like a proposal than a design, and the second semester's reports often contained more sizzle than content. This level of documentation is not at all related to the documentation that students would be expected to deliver to their management or peers in industry, where format is dictated and content is paramount. Also, the instructors of a new multi-disciplinary senior design program realized that if they were to start adding instruction to the course, they would need to do so gradually to minimize any negative impressions students would have toward attending class ("There was no class lectures last semester"). This paper describes the background of the UNC Charlotte program before these curricular changes. It also describes the deliverable documents that students now submit as assignments. The results were an improved identification of project capabilities and requirements as measured using a published rubric.
\end{abstract}

\section{Introduction}

Capstone design courses offer engineering students an opportunity to apply the skills they have learned throughout their undergraduate education to an applied engineering project. One of the main goals of the senior design course is to engage students in a project with real world implications that are similar to those they will face once the student enters the work force. In the past, nearly all of the senior design courses at UNC Charlotte encompassed student or faculty-generated projects. The course instructors provided minimal classroom instruction during the two-semester course and required minimal documentation at the end of each semester. This type of course format often leads to minimal student effort, minimal student output, and last-minute, end-of-semester document preparation. This should easily be seen as a shortcoming in any engineering curriculum.

A decision was made to integrate a multi-disciplinary senior design program that spans all of the departments within the College of Engineering at UNC Charlotte, based on the investigation of several university programs. The course instructors would form groups with three to four students containing diverse talents that would be representative of a typical engineering team in industry. Additionally, industry sponsors would be identified and incorporated into the program. These sponsors would be afforded the opportunity to initiate elective research projects in their respective areas of interest while working closely with seniors that the company may be interested in recruiting. 


\section{Content Assessment of Previous Courses}

A survey of senior design performance was conducted of the Electrical and Computer Engineering faculty at UNC Charlotte ${ }^{1}$. The goal of the survey was to document the level of project skills of the Electrical and Computer Engineering students while working on student or faculty-generated projects. The survey, which was conducted by gathering inputs from those educators who guided and graded senior design projects, is illustrated in Table 1.

Table 1: Survey given to educators who guide and grade the existing senior design program in the Electrical and Computer Engineering Department at UNC Charlotte to assess the student's project skills at the end of the two-semester course.

Survey (5=excellent, $1=$ non-existent)

\begin{tabular}{|l|c|}
\hline Question & Mean \\
\hline 1) Please rate your students' ability of setting clear goals for their projects. & 3.2 \\
\hline 2) Please rate your students' ability of identifying clear tasks to achieve their goals. & 3.19 \\
\hline 3) Please rate your students' ability of setting schedules for their tasks. & 3.19 \\
\hline 4) Please rate your students' ability of constructing the budget for their projects. & 3.4 \\
\hline $\begin{array}{l}\text { 5) Please rate your students' ability of identifying the resources needed to accomplish their } \\
\text { projects. }\end{array}$ & 3.38 \\
\hline 6) Please rate your students' ability of foreseeing potential risks involved in their projects. & 2.75 \\
\hline 7) Please rate your students' ability of creating contingency plans. & 2.5 \\
\hline 8) Please rate your students' ability of setting and attending regularly scheduled meetings. & 3.8 \\
\hline 9) Do your students provide their status reports on time? & 3.67 \\
\hline 10) Rate the quality of these status reports. & 3.46 \\
\hline 11) Do your students provide their final reports on time? & 4.06 \\
\hline 12) Please rate the quality of their final reports. & 3.81 \\
\hline 13) Rate your satisfaction with the final products of projects & 3.56 \\
\hline 14) Please rate your students' leadership skills. & 3.47 \\
\hline 15) Please rate your students' problem-solving skills. & 3.44 \\
\hline 16) Please rate your students' teamwork skills. & 3.87 \\
\hline $\begin{array}{l}\text { 17) Please rate your students' negotiation skills when a disagreement occurs during the } \\
\text { course of the project. }\end{array}$ & 3.67 \\
\hline $\begin{array}{l}\text { 18) In general, please rate your students' performance in meeting your / their customers' } \\
\text { expectations. }\end{array}$ & 3.44 \\
\hline $\begin{array}{l}\text { 19) Do your students make mid-term changes during the execution process of their } \\
\text { projects? YES or NO }\end{array}$ & YES: $75 \%$ \\
\hline $\begin{array}{l}\text { 20) Do your students use any project management tools (e.g., Gantt charts, work } \\
\text { breakdown structure, project network diagrams such as CPM and PERT, etc.)? YES or NO }\end{array}$ & No: $94 \%$ \\
\hline 21) In general, how complete are these projects when it is time for grading? Percentage: & $76 \%$ \\
\hline \hline
\end{tabular}


The overall performance of the students in meeting expectations was rated between "moderate" and "good", but closer to "moderate". Their project planning abilities (setting clear goals, tasks, schedules, budget, and resources) were also rated in the "moderate" category. Socio-cultural skills such as leadership and problem solving were identified as additional candidates for improvement. Furthermore, the students were not prepared to foresee risks and prepare contingency plans accordingly since these skills were rated between "poor" and "moderate".

The survey identified three distinct problem areas that could be targeted for improvement: 1) Project scope and work breakdown structure identification, 2) Project time and integration management, and 3) Project risk management and reporting.

\section{Industry-standard Deliverables}

Students participating in the industry sponsored senior design program are expected to produce industry-standard deliverables throughout the two-semester course. The following documents are suggested and supported in an earlier paper ${ }^{2}$ and include:

- Requirements and Capabilities

- Work Breakdown Structure

- Schedule (Gantt Chart)

- Risk Assessment and Mitigation Plan

- Project Budget

- Bill of Materials

- Purchase Orders

- Project Design Documentation

- Status Reports

- Change Requests

- Final Project Report

A group leader is identified for each team and held accountable for the production and updating of the project documents.

A graduating engineering student should have some level of project management knowledge and experience before they enter the workforce ${ }^{2}$. The student will likely be hired directly or promoted into a position with management responsibilities that combine engineering problems, human factors, financial issues and orchestrating a cross-functional team. The discipline of organizing and managing resources in such a way that these resources deliver all of the work required to complete a project within a defined scope, time and cost constraints is emphasized in the industry sponsored senior design program via project management and design instruction. The processes of initiating, planning, executing, controlling and closing are practiced by each team by producing documents that identify a work breakdown structure, risk assessment, and a Gantt chart.

\subsection{Requirements and Capabilities}

The Requirements and Capabilities document (Figure 1) is developed at the start of the first semester based on the project requirements and expected outcomes provided by the industry 
sponsor. The document is used to reinforce the disciplined application of scientific principles and techniques for developing, communicating, and managing the specific details of the project. The Requirements and Capabilities document also serves as the rubric with which the industry sponsor can verify that the end device has all of the desired functionality. To generate the document, students are instructed to first identify all relevant sources of requirements (capabilities, statement of work provided by the industry sponsor, proposals, etc.). Next, they determine what information is needed and analyze the gathered information looking for implications, inconsistencies and unresolved issues. Finally, they synthesize appropriate statements of the requirements and confirm their understanding of the underlying issues with the industry sponsor. The requirements of the project may change as development continues, but the original Requirements and Capabilities document remains intact. If alterations are required, a change request is submitted to the industry sponsor for approval.

Once the team's understanding of the sponsor's needs have been confirmed, they form a requirements verification-acceptance test plan to validate that all of the requirements have been met by the end of the second semester. The capabilities portion of the document illustrates what the device should be capable of doing, identifies constraints of the device, describes the device's operation, and how the group intends to demonstrate the device.

The document is assessed by the course instructors, the faculty mentors, and the sponsors based on a system of grading rubrics suggested by Estell and Hurtig ${ }^{3}$. This rubric (Figure 2) is provided to the students before the assignment is due so that they may ensure their document meets the high-level of standards the sponsor will expect.

\subsection{Work Breakdown Structure Identification and Schedule Development}

Students use the Work Breakdown Structure document (Figure 3) to identify as many individual tasks that need to be done for the entire project as possible. An initial list is usually produced during a group brainstorming session, and a time estimate for each task is assigned. The team then groups the tasks by precedence, that is, similar tasks that may depend on each other.

Finally, the individual tasks are assigned to the various team members. The students are required to enter all of this information into a Gantt chart (Figure 4) and produce an appropriate time line.

\subsection{Risk Assessment and Mitigation Plan}

After the Requirements and Capabilities document is complete and an appropriate time line has been established, students assemble a Risk Assessment and Mitigation plan document (Figure 5) identifying potential risks that could prevent the realization of their goals. Each risk is assessed based on the probability that the event will ever happen ( $3=$ likely, $2=$ possible, $1=$ unlikely), the impact the risk will have on the project if it does occur ( $3=$ severe, medium $=2,1=$ low), and the ease of mitigating the problem $(3=$ costly, $2=$ medium, $1=$ low or none $)$. The total score for each risk is calculated and used to rank the risks to identify the potential problems that could pose the biggest threats to the project's success. Emphasis is placed on identify and addressing the potential risks before they occur. 


\subsection{Bill of Materials, Project Budget and Purchase Orders}

A Bill of Materials (Figure 6) is produced describing the final product in terms of its assemblies, subassemblies, and basic parts. A hierarchical list of information is used as needed to describe the list of components and subassemblies. Once all of the required parts are listed, a Project Budget (Figure 7) is compiled and appropriate University purchase orders (Figure 8) are filed.

\subsection{Project Design Documentation}

A Project Design document is required by each group at the end of the first semester and reviewed by both the team's faculty mentor and industry sponsor. The document outlines the group's accomplishments to date and their ability to adhere to the requirements, capabilities and proposed time line. The format of this document is similar to the Capability and Requirements document. Additionally, each team produces a 30" x 40" poster to be displayed at an end of the semester banquet where they showcase their efforts to a wide variety of students, faculty and industry members.

\subsection{Status Reports}

Six status reports are required throughout the second semester to ensure the teams are making progress towards implementing the design they conceived during the first semester. Status reports outline their accomplishments related to the Requirements and Capabilities documents, updates to the timeline, shortcomings and requirements change requests if needed. The format of the status report is similar to the Capability and Requirements document.

\subsection{Final Project Report}

A final project report is required outlining the final design, cost and testing performed to verify that the end product conforms to the specified requirements and capabilities. The format of this document is similar to the Capability and Requirements document. Additionally, the students produce another 30"x 40 " poster to be displayed at an end of the second semester exposition and banquet where again they showcase their efforts to students, faculty, alumni, and industry members. Students with a physical end product will also display their deliverable device.

\section{Program Implementation}

Even though the students participating in the first year of the industry sponsored senior design program had not been exposed to the previous senior design course format, most were aware that the course structure was not very rigorous. Therefore, the course instructors initially had some concerns about adding too much instruction to the new course format that might create negative impressions by the students toward attending the class ("There was no class lectures last semester"). The potential for a negative impact was minimized by reinforcing lecture concepts with group exercises that were less structured than a typical classroom environment created by an instructor speaking to a class for the entire period. The group exercises also helped to develop relationships between new group members in a semi-structured environment that could continue to develop as the teams worked together outside of class. Specific industry-standard deliverable 
documentation was assigned and supported with lectures that contained numerous hands-on learning and team activities. In-class exercises were used to keep the students engaged by forming teams and working examples on flip chart paper that could be viewed by the entire class and discussed at the end of each lecture. The assignment of deliverable documentation that was due throughout the year also helped to avoid students working long hours at the end of the semester on their designs, since the design documents were assigned, completed, and submitted all throughout the year.

Before the industry sponsored senior design program could begin, industry sponsors had to be identified and convinced to invest their resources into the new senior design program. Most sponsors were asked to make a monetary donation to help offset the administrative costs associated with running the course and hosting several social functions to showcase the student's work, as well as purchase the necessary parts and equipment associated with each project. The sponsors were asked to submit a one-page description of the intended project, a one-page company profile, and the initial project requirements. Sponsors were provided with some guidelines for good projects that included: 1) A solid statement of work, 2) Civil, mechanical, electrical and/or computer based solutions that could be completed within a work envelope of 1,000 person-hours, 3) The company must be able to wait nine-months for the end product, 4) Project goals should allow for ample time for testing, 5) Complex projects should consider large or multiple teams, and 6) Project prototypes must be manufacturable under available machine shop or rapid prototyping facilities. In return, the companies were afforded the opportunity to profit from initiating elective research projects, collaborating with the UNC Charlotte research faculty, the creative talents of the students, and the opportunity to network with graduating seniors that they may be interested in recruiting.

At the beginning of the first semester, all of the students were provided a copy of the company documents submitted describing all projects, company profiles and initial requirements. Forming project groups and assigning students to each group was accomplished by requiring the students to rank their top three project choices and submit a resume and cover letter describing why they would be the best choice for a particular project. The resumes and cover letters were reviewed by the course instructors and the appropriate multi-disciplinary teams were formed based on project needs and student talents. A copy of every student resume was provided to all industry sponsors for future reference.

Grades for the first semester were assigned by the team's faculty mentor and based on the quality of the documents submitted and the team's ability to meet the goals contained within their timeline and requirements documents. The second semester grades were based on the quality of the group's status reports, final written report, project results, final presentation and peer evaluations.

\section{Case Studies of "Problem Groups"}

The implementation of the Multidisciplinary Senior Design program has not been without its problems. One must examine these problems in order to identify deficiencies of the program and make corrective actions. Nearly all of the problems are associated with team communications. 
In today's academic world students are not fully developing their communication skills. The Senior Design course has emphasized communication as an important part of the project completion. Students are encouraged to become involved in boundary spanning, utilizing communication skills to seek out answers from the strong intellectual talent that is available at the university. At the same time, they are also encouraged to communicate with industry partners and learn about the product requirements, past experience and market opportunities.

A sampling of problems encountered includes:

- Group 1: "We don't need your help" - In the first case, a group of the students refused to meet with the faculty adviser on a regular timely basis. Instead, these students worked directly with the industry sponsor. However, the faculty adviser felt that many of the students' abilities were underdeveloped. The faculty advisor tried to direct the students toward a more productive program by expanding their communications, but these students complained that he "expected too much of them."

- Group 2: "We are smarter than you" - In a similar project, students worked hard to develop cost reductions on an existing industrial product. Early on, they met with their faculty adviser, under his encouragement, and learned about cost reduction and design. After these ideas "occurred to them," they withdrew from the communication phase and began working as an independent group. Their education was severely limited by their inability to communicate on a regular basis with the expertise available.

- Group 3: "Us versus them 1" - One group was assembled with two electrical engineering students and two electrical engineering technology students. The personalities of all of the students were such that each pair did not think the other pair was listening to them. Intervention by the instructor and faculty mentor did not change the environment. The two technology students dropped the course, which left the remaining students with a large project and only two resources.

- Group 4: "If I ignore the problem, it will go away"- A team of two electrical engineering students and two electrical engineering technology students was created and paired with a faculty member from the Electrical and Computer Engineering department. The faculty member opted to take a passive mentoring roll, waiting for the students to find him when needed rather than requiring meetings on a regular basis. The team was not able to function with this much freedom, and since little was being expected of them little effort was put forth. A new faculty mentor was assigned to the group at the start of the second semester that is in touch with the group at least once a week, and the group has realized a marked improvement in productivity.

In each of these cases, the students made a conscious effort to forgo full communications with other individuals of the team (whether they be faculty, sponsors, or other students). To correct this problem, the program will include more team building and class activities on communications.

\section{Results}

The most important document of this effort is the Capabilities and Requirement document. This serves as the metric by which the sponsoring company (and the course instructors) can assess the 
success of the project. This document was collected and graded three times throughout the semester, though actual scores were not recorded for the first attempt. The results were that the capabilities and requirements were rated at the "Expert" level by the end of the first semester.

Table 2: Scoring history of Capabilities and Requirements Document throughout the semester (average)

\begin{tabular}{|l|c|c|c|}
\hline Grading Rubric & $\begin{array}{c}10 / 4 / 06 \\
\text { (estimated) }\end{array}$ & $10 / 20 / 06$ & $12 / 7 / 06$ \\
\hline Visual Format and Organization & 2.8 & 3.0 & 3.0 \\
\hline Language (Word Choice, Grammar) & 2.0 & 3.0 & 3.0 \\
\hline Capabilities & 2.0 & 2.5 & 3.0 \\
\hline Requirements & 1.5 & 2.7 & 3.0 \\
\hline Demo Test Plan & N/A & 2.0 & 2.5 \\
\hline Acceptance Test Plan & N/A & 2.0 & 2.5 \\
\hline Use of Subject Matter Experts and Sources & 2.0 & 2.5 & 2.7 \\
\hline
\end{tabular}

The end of semester evaluation for the first half of the course included both positive and negative comments. The positive comments centered on the opportunity of working with companies. The negative comments identified problems that were known and will be corrected during the next implementation of the program:

- This was a very good class. Everything will be very beneficial for our future careers.

- I love the multidisciplinary idea; it is so much better than the normal senior design.

- I learned a lot about the business end of industry about a Work Breakdown Structure, a Bill of Materials, Requirements Documents, etc. A very interesting class that gave me a little bit of industry experience.

- Great class. Look forward for next year.

- This class really gives students an unforgettable experience. They gain experience in industry, documents (business) required, \& w/developing posters. This class should continue. For the first semester ever taught, it was fabulous.

- Our company did not seem fully prepared at the beginning of the semester. Overall, the format of the class is excellent and I enjoyed working with the company.

- Need to get Purchase Order stuff sorted out. My senior design project would have been more effective if I had money early on.

- Wonderful class. However, the senior design project I was assigned is not one I am terribly interested in

As a testament to the value of this program and its objectives, many students had received job offers from their sponsoring company by the halfway point of the project. Participating companies were so excited about the results of the designs after the first semester that they wrote unsolicited letters appreciation to the university Provost and the College of Engineering Dean. Many verbal kudos were also expressed by the companies during the design exposition banquet.

All forms, spreadsheets, and documents described in this paper are available from the website http://www.srdesign.uncc.edu. 


\section{Conclusions and Future Work}

A multi-disciplinary industry sponsored senior design course has been developed and integrated into the College of Engineering curriculum at UNC Charlotte. Shortcomings in the studentproject generated senior design courses used by the engineering department in previous years have been identified and the new program has been developed to concentrate on these problem areas. The industry-sponsored course affords students an opportunity to work on real-world problems using project management skills along with design and technical skills. The twosemester course breaks the class into multi-disciplinary groups of three to four students that work on industry defined problems with engineers from the sponsoring company. Students benefit from networking not only with the sponsor of their particular project but also with other industry sponsors at several project presentation expos. Industry partners profit from the talent of students and faculty members at UNC Charlotte working on innovative solutions to company defined research projects.

The program is expected to grow as more industry sponsors and students become aware of the successful new course format. The increased growth will lead to an increase in both financial and administrative duties and justify the hiring of a part-time staff member to handle both responsibilities. The program also requires continuing efforts to increase awareness both within the industry sector as well as with local politicians and the community. All of these parties stand to benefit from the program's success as the university graduates students whom are better prepared for careers in industry.

\section{Bibliography}

1. Conrad, James M. and Sireli, Yesim, "Learning Project Management Skills in Senior Design Courses," Proceedings of the 2005 Frontiers in Education Conference, Indianapolis, IN, pp. F4D-1 to 6, October 2005.

2. Conrad, James M., "Determining How to Teach Project Management Concepts to Engineers," Proceedings of the 2006 ASEE Conference, June 2006.

3. Estell, John K; Hurtig, Juliet, "Using Rubrics for the Assessment of Senior Design Projects", Proceedings of the 2006 ASEE Annual Conference \& Exposition: Excellence in Education; Chicago, IL; USA; 18-21 June 2006. 


\section{Appendix}

UNC Charlotte Senior Design

Project: Xxxxxx

Author: Yyyyyy
Rev. A
Page 1 of 3

Requirements Document Date: $2006-\mathrm{xx}-\mathrm{xx}$

\section{Xxxxxx Project - Capabilities and Requirements}

\begin{tabular}{|l|l|l|l|}
\hline Date & Revision & Author & Comments \\
\hline $2006-\mathrm{xx}-\mathrm{xx}$ & PA1 & Yyyyyy & Original Document \\
\hline & & & \\
\hline & & & \\
\hline & & & \\
\hline
\end{tabular}

Table of Contents
Overview

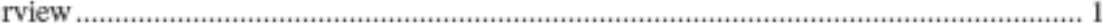

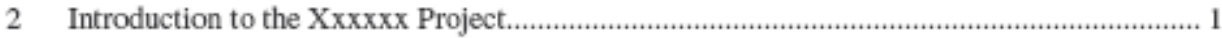
3 Sources of Requirements - Documents and Persons .............................................................. 1
4 Capabilities ............................................................................................................................................ 2
5 Functional Requirements .............................................................................................. 2
6 Non-functional Requirements ............................................................................................ 2

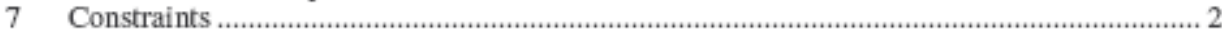

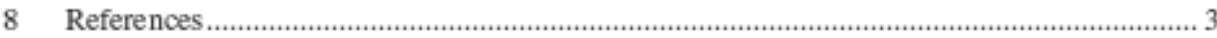

\section{Overview of this Document}

This document describes Capabilities, Requirements, Acceptance Test Plan, and Demonstration Plan of the Xxxxxx project and of its end-product. The team member who is identified as the Principal Engineer is responsible to maintain this document.

\section{Overview of the Xxxxxx Project}

Include in here some detail of the project and end-product. This can be lifted from the Statement of Work.

\section{Sources of Requirements and Capabilities - Documents and Persons}

The following documents were consulted for these capabilities and requirements:

- Customer Vvvvvvv

- Xxxxxx Statement of Work

- Xxxxxx Proposals

- Xxxxxx company-supplied requirements

- Zzzzzz project Capabilities and Requirements document

- Zzzzzz Final Report

- Zzzzzz Lessons Learned document

The following people were consulted for input to the $\mathrm{Xxxxxx}$ requirements:

- Engineer A 
UNC Charlotte Senior Design - Requirements Report Rubric - Preliminary (9/27/06)

Project:

Date:

Student(s):

\begin{tabular}{|c|c|c|c|c|}
\hline & 3-Expert & 2-Practitioner & 1-Apprentice & 0 - Novice \\
\hline $\begin{array}{l}\text { Visual } \\
\text { Format and } \\
\text { Organization }\end{array}$ & $\begin{array}{l}\text { - Group has used the } \\
\text { suggested template. } \\
\text { - The document is visually } \\
\text { appealing ande asily } \\
\text { navigated. } \\
\text { - Appropriate typography } \\
\text { and usage of white space } \\
\text { are used as appropriate to } \\
\text { separate blocks of text } \\
\text { and addemphasis. }\end{array}$ & 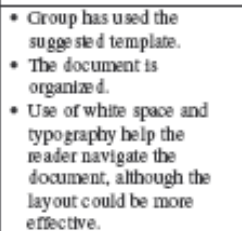 & 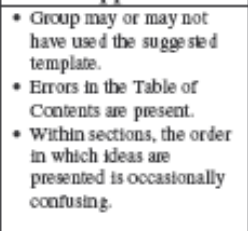 & $\begin{array}{l}\text { - Group has not used the } \\
\text { suggested termplate. } \\
\text { - The document is not } \\
\text { visually appeating and } \\
\text { there are few "cues" to } \\
\text { help the reader ravigate } \\
\text { the document. } \\
\text { - There is no apparent } \\
\text { ordering of paragraphs. }\end{array}$ \\
\hline $\begin{array}{l}\text { Language } \\
\text { (Word } \\
\text { Choice, } \\
\text { Grammar) }\end{array}$ & $\begin{array}{l}\text { - Sentenoes are complete } \\
\text { and grammatcical. They } \\
\text { flow together easily. } \\
\text { - Words are chosen for } \\
\text { their prectise me aning } \\
\text { - Engineering terms and } \\
\text { Jargon are ued correctly. } \\
\text { - No misspelled words are } \\
\text { pre sent. }\end{array}$ & 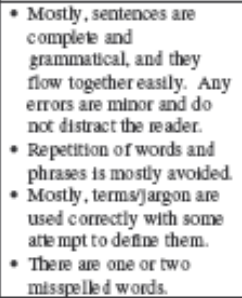 & $\begin{array}{l}\text { - In a few places, errors in } \\
\text { sentenoe structure and } \\
\text { grammar distract the } \\
\text { reader and interfere with } \\
\text { me anting. } \\
\text { - Word choloe could be } \\
\text { improved. } \\
\text { - Occasically, technical } \\
\text { jargco is used without } \\
\text { definition. } \\
\text { - There are a ow } \\
\text { misspelled words. }\end{array}$ & $\begin{array}{l}\text { - Errors in sentence } \\
\text { structure and grammar } \\
\text { frequently distract the } \\
\text { reader and interfere with } \\
\text { meaning. } \\
\text { - There ts unnecessary } \\
\text { repettion of the same } \\
\text { words and phrases. } \\
\text { - There is an overuse of } \\
\text { jargon and dechnical terms } \\
\text { without definition. } \\
\text { - There are many } \\
\text { misspelled words. }\end{array}$ \\
\hline Capabilities & $\begin{array}{l}\text { - All ifems are assigned a } \\
\text { unique identiner (Le. } \\
\text { CAP001). } \\
\text { - Thems represent function- } \\
\text { ality of the end product, } \\
\text { but are not necessarily } \\
\text { bounds co the product. } \\
\text { - The se are not } \\
\text { requirements, constraints, } \\
\text { or specincartions. }\end{array}$ & 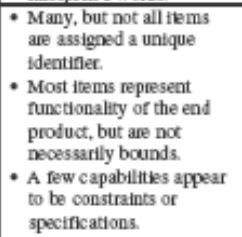 & 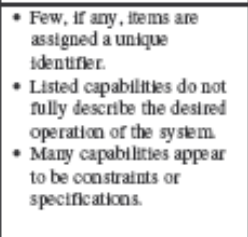 & $\begin{array}{l}\text { - No terms are assigned a } \\
\text { untque identiner. } \\
\text { - Listed capabilitites do not } \\
\text { de scribe the desifed } \\
\text { operation of the system }\end{array}$ \\
\hline Requirements & 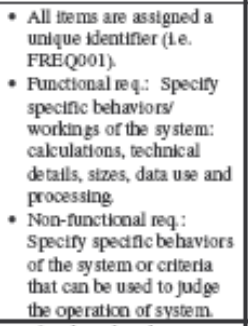 & 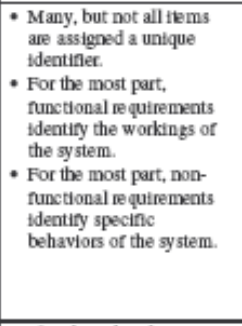 & 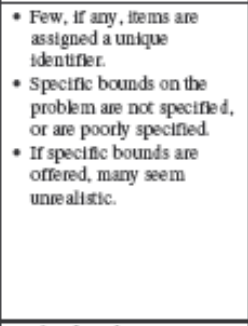 & $\begin{array}{l}\text { - No items are assigned a } \\
\text { unique identiner. } \\
\text { - Listed requirements do } \\
\text { not bound the de sired } \\
\text { workings of the system. } \\
\text { - If specinc bounds are } \\
\text { offered, most seem } \\
\text { uniealistic. }\end{array}$ \\
\hline $\begin{array}{l}\text { Demo Test } \\
\text { Plan } \\
\text { (Graded } \\
10 / 20 / 06 \text { ) }\end{array}$ & 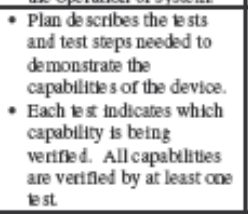 & $\begin{array}{l}\text { - Plan describes the tests } \\
\text { and lest steps needed to } \\
\text { demonstrate most of the } \\
\text { capabelitiks of the device. } \\
\text { - Most capabilities are } \\
\text { verifed by at least one } \\
\text { test. }\end{array}$ & 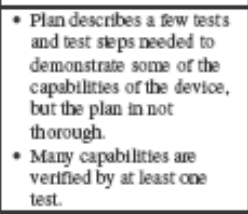 & $\begin{array}{l}\text { - Plan de scribes a very } \\
\text { small number of tests and } \\
\text { test steps nee ded to } \\
\text { demonstrate a small part } \\
\text { of the capabilitities of the } \\
\text { devioe. } \\
\text { - Tests poorly demonstrate } \\
\text { capabilitles of system. }\end{array}$ \\
\hline $\begin{array}{l}\text { Acceptance } \\
\text { Test Plan } \\
\text { (Graded } \\
10 / 20 / 06 \text { ) }\end{array}$ & 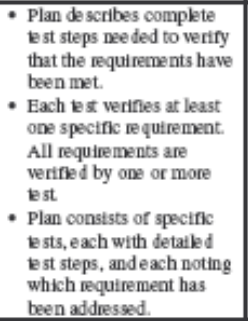 & $\begin{array}{l}\text { - Includes most tests } \\
\text { needed to verify that the } \\
\text { requirements have been } \\
\text { mot. } \\
\text { - Most requirements have } \\
\text { been verified by at least } \\
\text { one te st } \\
\text { - Most tests have detalked } \\
\text { test steps, with each } \\
\text { nocing which requirement } \\
\text { has been addresed. }\end{array}$ & $\begin{array}{l}\text { - Plan describes a few tests } \\
\text { and test steps needed to } \\
\text { demonstrate some of the } \\
\text { requirements of the } \\
\text { devioe, but the plan in not } \\
\text { thorough. } \\
\text { - Many requirements are } \\
\text { verined by ar least coe } \\
\text { test. }\end{array}$ & $\begin{array}{l}\text { - Plan de scribes a very } \\
\text { small number of tests and } \\
\text { Est steps nee ded to verify } \\
\text { system requirements of } \\
\text { the devioe. } \\
\text { - Tests poorly verify the } \\
\text { system requirements. }\end{array}$ \\
\hline $\begin{array}{l}\text { Use of } \\
\text { Subject } \\
\text { Matter } \\
\text { Experts and } \\
\text { Sources } \\
\text { Score: } \\
\end{array}$ & $\begin{array}{l}\text { - Prior work and sources of } \\
\text { requirements are } \\
\text { acknow ledged by } \\
\text { referring to people. } \\
\text { assumptons, and } \\
\text { background. }\end{array}$ & $\begin{array}{l}\text { - with an occastional } \\
\text { oversight, prior work and } \\
\text { souroes of requifements } \\
\text { are acknow lidged by } \\
\text { referring to people, } \\
\text { assumptons, and } \\
\text { background. }\end{array}$ & $\begin{array}{l}\text { - On several instanoes, } \\
\text { souroes of requirements } \\
\text { are not stated when } \\
\text { appropratafe. }\end{array}$ & $\begin{array}{l}\text { - Little attempt is made to } \\
\text { identify the source of } \\
\text { requirements. }\end{array}$ \\
\hline
\end{tabular}

Figure 2: Grading Rubric for Capabilities and Requirements Document 


\begin{tabular}{|c|c|c|c|c|c|c|c|}
\hline \multicolumn{2}{|c|}{ Task } & hrs & Responsible & $\mathbf{A}$ & B & $\mathbf{C}$ & D \\
\hline \multicolumn{2}{|c|}{ Total Hours } & 91 & & 38.5 & 18.5 & 17 & 17 \\
\hline & & & & & & & \\
\hline \multicolumn{8}{|c|}{$\mathrm{PM}$} \\
\hline & $\begin{array}{l}\text { Develop WBS and } \\
\text { schedule }\end{array}$ & 0 & & & & & \\
\hline & Review WBS & 0 & & & & & \\
\hline & $\begin{array}{l}\text { Modify WBS \& } \\
\text { Estimates }\end{array}$ & 0 & & & & & \\
\hline & $\begin{array}{l}\text { Create MS Project } \\
\text { File }\end{array}$ & 0 & & & & & \\
\hline & Review Project Plan & 0 & & & & & \\
\hline & Modify Project Plan & 0 & & & & & \\
\hline & Identify Risks & 6 & All & 1 & 1 & 1 & 1 \\
\hline & $\begin{array}{l}\text { Develop mitigation } \\
\text { plan }\end{array}$ & 2 & $A, B$ & 1 & 1 & & \\
\hline & $\begin{array}{l}\text { Review mitigation } \\
\text { plan }\end{array}$ & 2 & $\begin{array}{l}\text { A, B, Mentor, } \\
\text { Sponsor }\end{array}$ & 0.5 & 0.5 & & \\
\hline & Monitor Project & 20 & A & 20 & & & \\
\hline & $\begin{array}{l}\text { Weekly group } \\
\text { project meetings }\end{array}$ & 40 & $\mathrm{~A}, \mathrm{~B}, \mathrm{C}, \mathrm{D}$ & 10 & 10 & 10 & 10 \\
\hline & Projects reports & 0 & & & & & \\
\hline
\end{tabular}

Figure 3: Work Breakdown Structure Document 


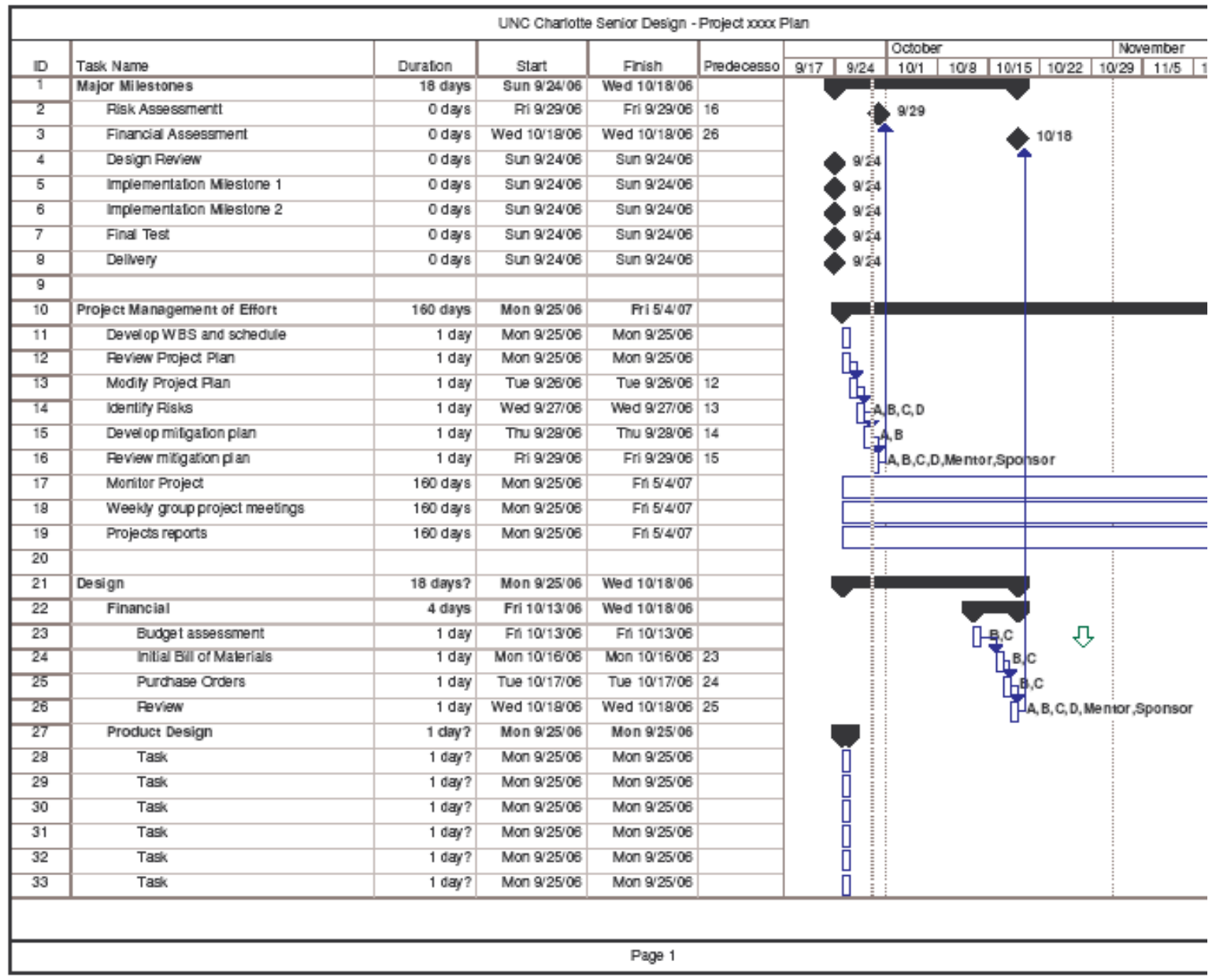

Figure 4: Example of a Project Gantt Chart

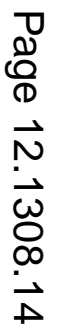




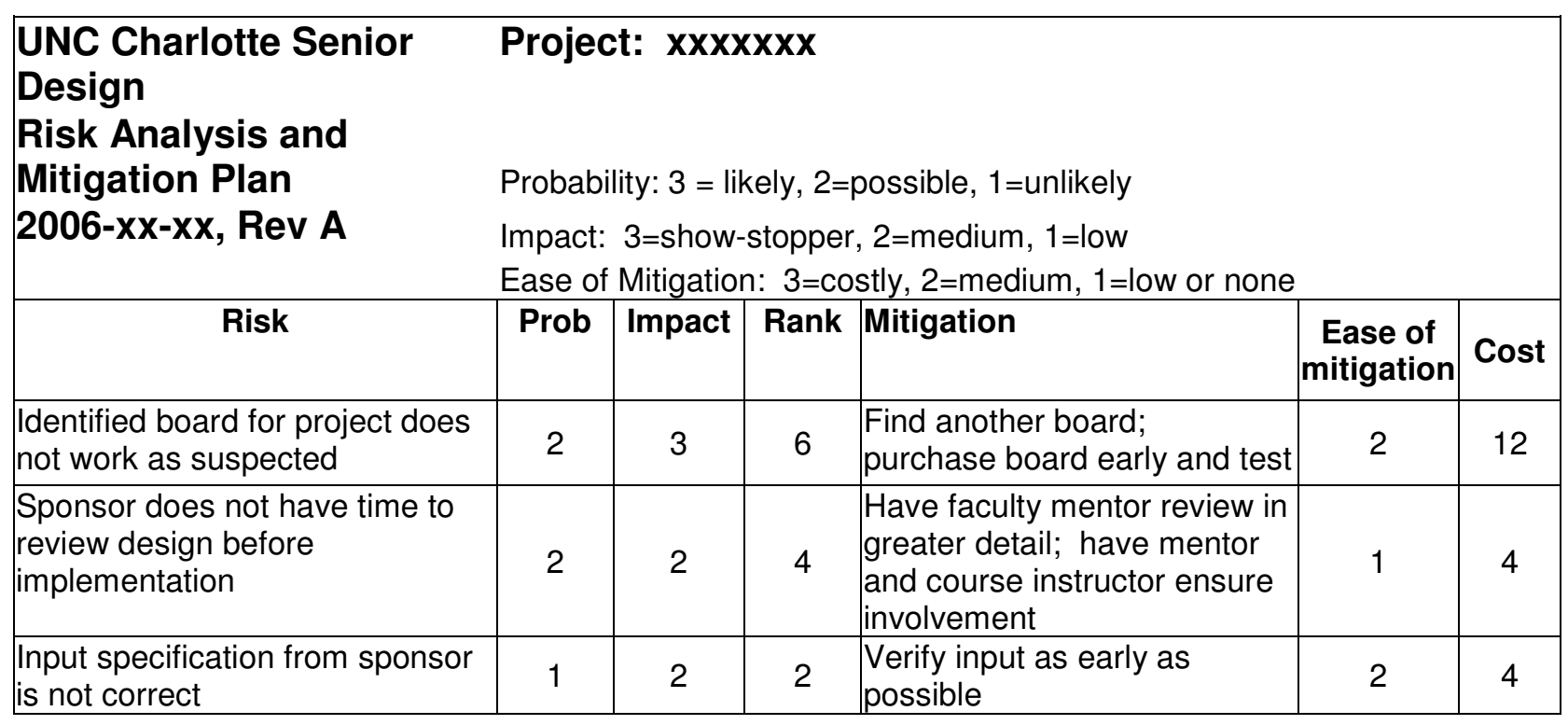

Figure 5: Risk Analysis and Mitigation Plan Example

\begin{tabular}{|c|c|c|c|c|}
\hline \multicolumn{5}{|c|}{$\begin{array}{lr}\text { UNC Charlotte Senior } & \text { Project: } \\
\text { Design } & \text { xxxxxxx } \\
\text { Project Bill of Materials for End Project }\end{array}$} \\
\hline \multirow[t]{8}{*}{ Item } & Qty & Price per & Total & Source \\
\hline & & & $\$ 0.00$ & \\
\hline & & & $\$ 0.00$ & \\
\hline & & & $\$ 0.00$ & \\
\hline & & & $\$ 0.00$ & \\
\hline & & & $\$ 0.00$ & \\
\hline & & & $\$ 0.00$ & \\
\hline & & & $\$ 0.00$ & \\
\hline Total & & & $\$ 0.00$ & \\
\hline
\end{tabular}

Figure 6: Bill of Materials Document 


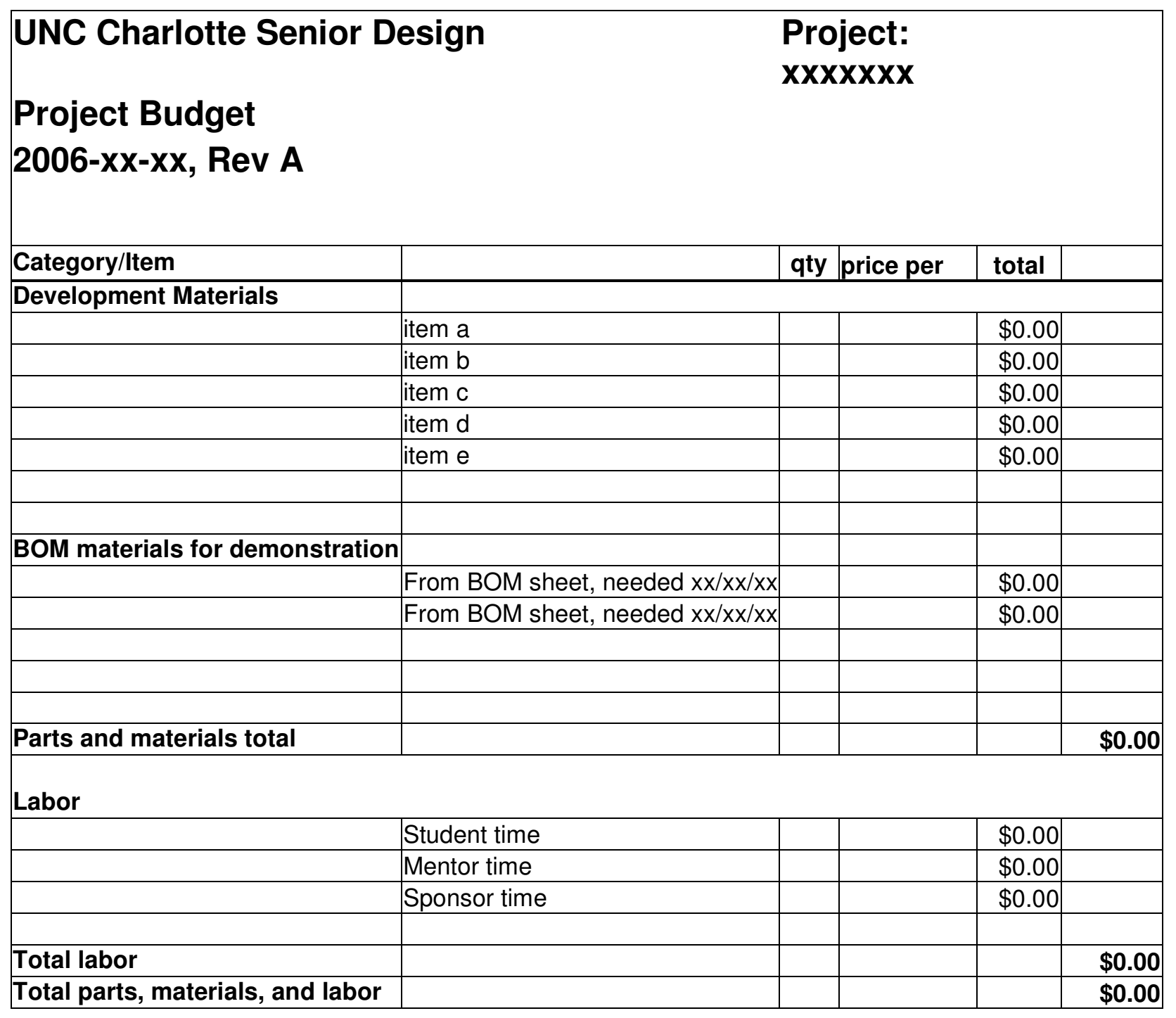

Figure 7: Project Budget Document 


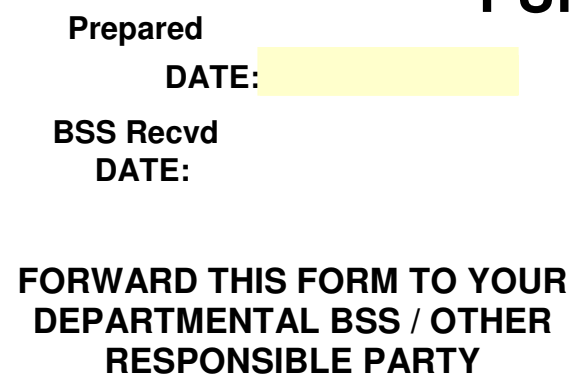

\section{PURCHASE REQUISITION}

PURCHASE ORDER NO. REQUISITION NO. FUND / INDEX NUMBER DEPARTMENT BLDG. / ROOM Project $x x x x x$ MARK FOR TELEPHONE Senior Design Program Senior Design Program

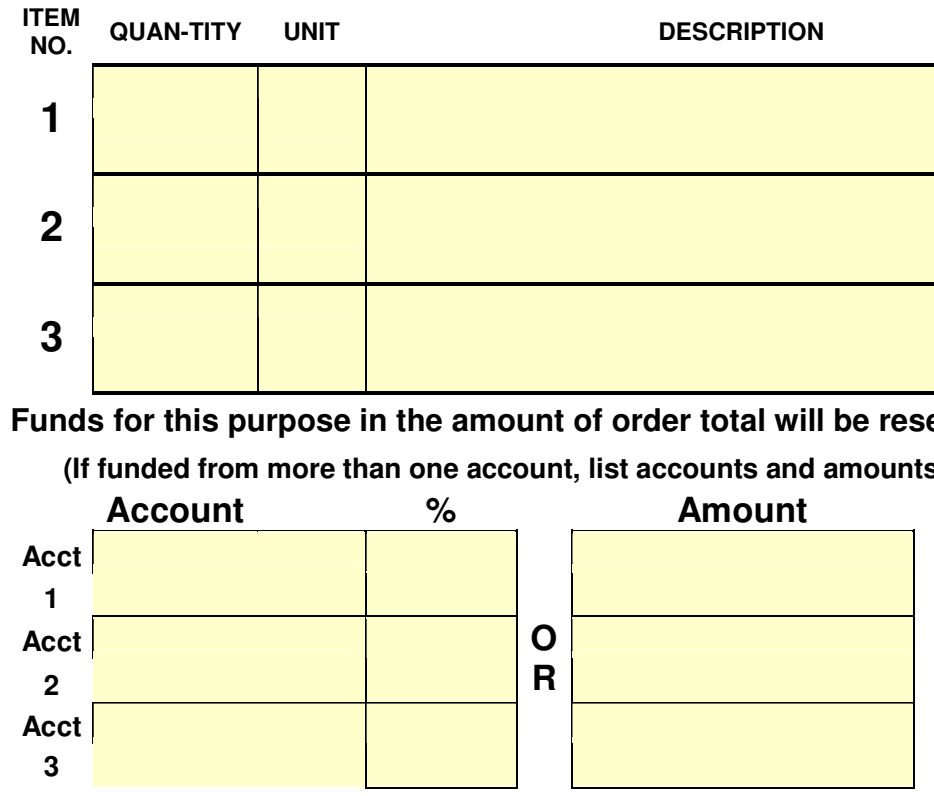

UNIT PRICE TOTAL PRICE

\section{Suggested Vendors:}

\begin{tabular}{|l|l|l|}
\hline & & \\
\hline & & \\
\hline & & \\
\hline
\end{tabular}

Sole Source, attach justification on next sheet or attach as separate file. Form attached to your email indicates your approval. If manually submitted, an authorized individual's signature is required:

Figure 8: Purchase Requisition Document 